Original Research Paper

\title{
Pelaksanaan Workshop dan Pelatihan Digital Marketing Sebagai Upaya untuk Meningkatkan Promosi dan Pemasaran Produk UMKM di Kelurahan Rakam Agar Semakin Maju dan Berkembang
}

\author{
Ahmad Jupri ${ }^{*}$, Eka S Prasedya ${ }^{2}$, Tapaul Rozi ${ }^{3}$, Ambrosia Christava Niwanoti Serrao ${ }^{4}$, Baiq Yolanda Ika \\ Anggari $^{5}$, Baiq Alia Zuhro Mustikawati ${ }^{6}$

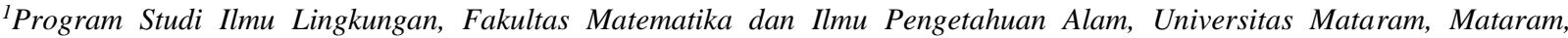 \\ Indonesia; \\ ${ }^{2}$ Program Studi Biologi, Fakultas Matematika dan Ilmu Pengetahuan Alam, Universitas Mataram, Mataram, Indonesia; \\ ${ }^{3}$ Program Studi Ilmu Produksi Ternak Fakultas Peternakan, Universitas Mataram, Mataram, Indonesia; \\ ${ }^{4}$ Fakultas Hukum, Universitas Mataram, Mataram, Indonesia; \\ ${ }^{5}$ Fakultas Ilmu Sosial Dan Politik, Universitas Mataram, Mataram, Indonesia; \\ ${ }^{6}$ Fakultas Ekonomi Dan Bisnis, Universitas Mataram, Mataram, Indonesia.
}

https://doi.org/10.29303/jpmpi.v3i2.1045

Sitasi: Jupri, A., Prasedya, E. S., Rozi, T., Serrao, A. C. N., Anggari, B. Y. I \& Muskiwati. (2022). Pelaksanaan Workshop dan Pelatihan Digital Marketing Sebagai Upaya untuk Meningkatkan Promosi dan Pemasaran Produk UMKM di Kelurahan Rakam Agar Semakin Maju dan Berkembang. Jurnal Pengabdian Magister Pendidikan IPA, 5(1)

\section{Article history}

Received: 10 November 2021

Revised: 01 Februari 2022

Accepted: 05 Februari 2022

*Corresponding Author:

Ahmad Jupri, Program Studi

Ilmu Lingkungan, Fakultas

Matematika dan Ilmu

Pengetahuan Alam, Universitas

Mataram, Mataram, Indonesia;

Email: juprizikril@gmail.com

\begin{abstract}
Kelurahan Rakam merupakan salah satu daerah di wilayah Lombok Timur yang cukup berkembang di bidang perdagangan dan masyarakatnya memiliki berbagai macam jenis profesi salah satunya adalah pedagang. Sebagian besar penduduk berprofesi sebagai pemilik UMKM (Usaha Mikro Kecil Menengah) sehingga memerlukan pemahaman dan pengetahuan serta skill tentang berwirausaha. Workshop ini bertujuan untuk membantu perkembangan UMKM yang ada di wilayah Provinsi Nusa Tenggara Barat Khususnya di wilayah Kelurahan Rakam, Kabupaten Lombok Timur. Salah satu strategi yang dapat ditempuh adalah dengan memanfaatkan digital marketing, Teknik yang dilakukan menyiapkan alat yang digunakan untuk melakukan pemasaran seperti: website, akun media sosial, identitas brand dan produk, unggahan blog, jejak online (review, feedback dari pelanggan,dan lain-lain). Kedua, siapkan konten yang menarik perhatian dan shareable. Konten dapat berupa foto, video, tulisan atau yang lainnya. Kita juga harus menentukan tujuan pemasaran dan target pasar yang disesuaikan dengan konten. Ketiga, mulai menggunggah dan selanjutnya evaluasi setiap unggahan di setiap social media yang dimiliki, tentukan mana yang memberikan feedback, kemudian yang terakhir masuk dan bergabung dengan forum marketplace public. Dalam workshop tersebut disampaikan hal-hal yang perlu disiapkan agar terwujudnya digital marketing. Melalui penelitian ini diharapkan Pelaku UMKM mengetahui cara atau strategi yang diterapkan untuk dapat membantu perkembangan UMKM agar lebih kreatif dan inovatif yang ada di wilayah Kelurahan Rakam.
\end{abstract}

Keywords: UMKM; Digital Marketing; Kreatif; Inovatif.

Provinsi Nusa Tenggara Barat. Posisi wilayah Kelurahan Rakam terletak antara $116^{0}-117^{0}$ Bujur Timur dan $8^{0}-9^{0}$ Lintang Selatan pada ketinggian $130 \mathrm{~m}$ dpl, dengan batas-batas wilayah sebagai berikut: Sebelah Utara Kelurahan Pancor kec. 
Selong, sebelah selatan kelurahan Denggen kec. Selong, sebelah barat kelurahan Majidi kec. Selong, sebelah timur Dasan Lekong kec. Sukamulia dan Desa Keselet kec. Sakra. Kelurahan Rakam memiliki luas wilayah 208,80 Ha dan terdiri dari 4 Lingkungan yaitu Bagek Longgek Timur, Bagek Longgek Barat, Batu Belek Timur dan Batu Belek Barat. Kelurahan Rakam memiliki kapasitas penduduk sebesar 7.768 jiwa. Jarak dari Kelurahan Rakam ke pusat pemerintahan Kecamatan maupun Kabupaten tidak terlalu jauh dan dengan waktu tempuh yang tidak terlalu lama. Jarak tempuh ke Ibu kota Kecamatan maupun Kabupaten hanya sekitar 1,5 km dan dapat ditempuh dalam waktu lebih kurang 5 menit dengan menggunakan kendaraan bermotor. Sedangkan jarak tempuh ke Ibukota Provinsi sejauh lebih kurang $52 \mathrm{~km}$ dan dapat ditempuh dalam waktu sekitar 1 Jam dengan alat transportasi darat berupa kendaraan bermotor roda dua atau roda empat.

Kelurahan Rakam secara umum terbilang cukup maju, baik secara infrastruktur maupun adminstratif. Kelurahan ini bergerak dan berfokus pada bidang pertanian, perdagangan dan Jasa. Karena letaknya yang cukup strategis Kelurahan Rakam terbilang cukup maju di sektor perdagangannya ditambah lagi kelurahan ini berada di dekat Pasar Pancor yang notabene merupakan wilayah pusat perdagangan yang ada di daerah Lombok Timur. Masyarakat di Kelurahan Rakam sendiri memiliki beragam jenis profesi mulai dari petani, peternak, pedagang dan sebagainya. Sebagian besar masyarakatnya berprofesi sebagai Pemilik UMKM (Usaha Mikro Kecil Menengah) atau yang biasa kita sebut Industri Rumah Tangga. UMKM memiliki peranan penting bagi perkembangan laju ekonomi di masyarakat. UMKM adalah kepanjangan dari Usaha Mikro, Kecil, dan Menengah (Purwaningsih et al., 2020).

Menurut Undang-Undang Nomor 20 Tahun 2008 tentang Usaha Mikro, Kecil, dan Menengah, UMKM atau usaha mikro merupakan usaha milik perseorangan atau badan usaha perorangan yang produktif dan memenuhi kriteria yang ditulis oleh Undang-Undang. Sementara itu, usaha kecil kerap dimaknai sebagai usaha ekonomi produktif yang berdiri sendiri, yang dilakukan oleh perorangan atau badan usaha (Angellia et al., 2020). Adanya UMKM dipercaya mampu membantu perekonomian di Indonesia. Pasalnya, melalui UMKM akan membentuk lapangan kerja baru dan meningkatkan taraf hidup masyarakat (Wahyu, 2021). Produk-produk yang dihasilkan dari Industri-industri Rumah Tangga yang berada di kelurahan Rakam terdiri dari berbagai jenis produk makanan mulai dari : Kripik Talas, Kerupuk Soda, Pisang Sale, Rengginang, Bakso, Jajanan Lokal dan lain-lain. Proses produksinya pun masih terbilang cukup sederhana.

Namun seiring berjalannya waktu ada beberapa permasalah dan hambatan yang dialami oleh para pemilik UMKM tersebut khususnya di bidang Pemasaran produk yaitu kurangnya Sumber Daya Manusia yang kreatif dan terampil dalam memasarkan produk-produk hasil usaha yang ada di Kelurahan Rakam. Jangkauan pemasaran produk hasil usaha tersebut dibilang masih cukup kecil dan belum berkembang sehingga produk tersebut hanya diketahui oleh penduduk sekitar wilayah kelurahan Rakam. Ditambah lagi adanya pandemi COVID-19 ini membuat UMKM-UMKM tersebut mengalami kemunduran dan keterhambatan sehingga usaha mereka tidak berjalan seperti sebelum adanya pandemi tersebut.

Berangkat dari hal tersebut, melalui program KKN dengan Tema Kewirausahaan ini kami selaku anggota $\mathrm{KKN}$ berusaha untuk membantu mengatasi permasalahan ini dengan bekerjasama dengan pemerintah Kelurahan dan lembaga yang terkait khusunya di Kelurahan Rakam dengan melakukan beberapa program kerja utama yang berkaitan dengan pemberdayaan masyarakat guna meningkatkan kualitas sumber daya manusia di Kelurahan Rakam yang mana merupakan inti dari sebagian besar segala permasalahan yang ada. Salah satunya dengan mengadakan Workshop tentang Pelatihan digital marketing untuk menambah pengetahuan dan pemahaman masyarakat dengan memanfaatkan teknologi modern.

Digital Marketing adalah sebuah kegiatan pemasaran atau promosi sebuah brand produk menggunakan media digital atau internet, tujuan dari digital marketing adalah untuk menarik konsumen dan calon konsumen secara lebih cepat serta menjangkau pasar yang lebih luas (Jupri et al., 2021). Menurut para ahli Struggles (2009) "Digital marketing menggunakan perkembangan dunia digital untuk melakukan periklanan yang tidak digembar-gemborkan secara langsung akan tetapi memiliki efek yang sangat berpengaruh. Dengan adanya digital marketing, kegiatan promosi dan 
pemasaran produk-produk hasil UMKM tersebut akan lebih mudah dilakukan sehingga UMKMUMKM tersebut akan semakin maju dan berkembang.

\section{Metode}

\section{Waktu dan Tempat}

Program KKN Tematik Unram 2021 ini dilakukan di Kelurahan Rakam Selong Lombok Timur. Kegiatan ini dimulai pada 21 Juni 2021 sampai dengan 5 Agustus 2021.

\section{Kegiatan}

Bentuk dari kegiatan dalam program ini adalah Pelaksanaan workshop tentang Digital Marketing di kelurahan Rakam pada tanggal 7 Juli 2021 untuk mengembangkan usaha dengan melakukan pelatihan dan membantu owner UMKM-UMKM yang ada di kelurahan Rakam agar produknya mampu dijual hingga keluar daerah. Kegiatan workshop ini juga sangat membantu para Umkm yang ada di Kelurahan Rakam. Agar terciptanya digital marketing ini terdapat beberapa hal yang harus di siapkan yaitu:

- Pertama, siapkan alat yang digunakan untuk melakukan pemasarannya. Beberapa alat bantu yang dapat digunakan dalam digital marketing seperti: website, akun media sosial, identitas brand dan produk, unggahan blog, jejak online (review, feedback dari pelanggan,dan lain-lain). Dalam dunia digital marketing, alat bantu ini merupakan aset bagi Anda, jadi uruslah dengan baik.

- Kedua, siapkan konten yang menarik perhatian dan shareable. Konten dapat berupa foto, video, tulisan atau yang lainnya. Kita juga harus menentukan tujuan pemasaran dan target pasar yang disesuaikan dengan konten.

- Ketiga, Kita dapat memulai menggunggah dan selanjutnya evaluasi setiap unggahan di setiap social media yang dimiliki, tentukan mana yang memberikan feedback dan fokuslah dalam beberapa aset yang memberikan feedback yang baik bagi bisnis kita.

- Langkah selanjutnya yang dapat dilakukan adalah masuk dan bergabunglah dengan forum marketplace public. Usahakan profil bisnis kita bagus dan menarik, karena akan berpengaruh terhadap citra brand.

\section{Hasil dan Pembahasan}

Pelaksanaan dan pelatihan promosi digital marketing merupakan salah satu dari program kerja utama kelompok KKN kami dikelurahan Rakam. Kegiatan workshop ini kami laksanakan pada tanggal 7 Juli 2021 bertempat di kantor kelurahan Rakam dengan mengundang seorang Narasumber.

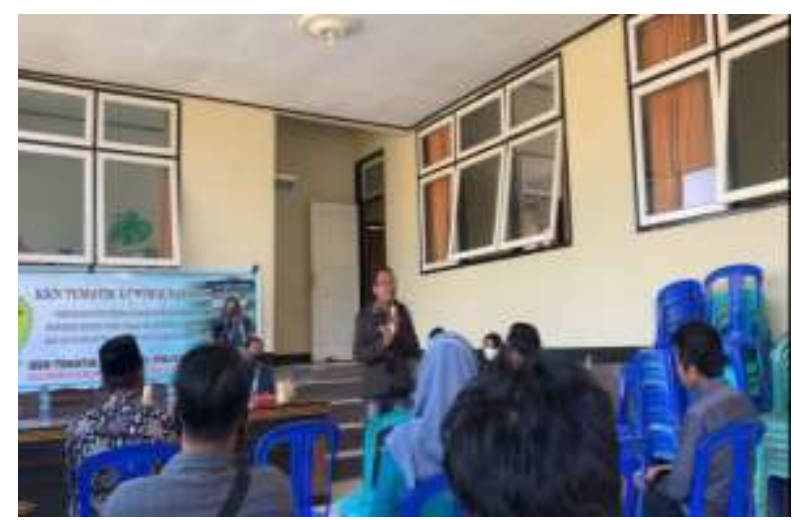

Gambar 1. Kegiatan Sosialisasi Digital Marketing

Narasumber yang di undang oleh kelompok KKN kami adalah seseorang yang sudah berpengalaman di dunia kewirausahaan. Beliau adalah Bapak Muhammad Maliki seorang Pembina UMKM wilayah Lombok timur. Dalam acara workshop tersebut, bapak Maliki memberikan berbagai pengetahuan dan motivasi terkait cara pemasaran dan promosi suatu produk usaha melalui aplikasi-aplikasi market place yang terdapat pada media sosial. Beliau juga memberikan sebuah arahan pada salah satu UMKM yang sudah cukup berkembang yaitu UMKM Kripik Talas Romantis milik Pak Samsul Rizal. Selain memberikan arahan tentang promosi melalui media sosial pak Maliki juga memberikan saran terkait branding dan pengemasan produk tersebut agar lebih menarik. Beliau juga memberikan pengetahuan tentang cara memanajemen suatu usaha agar usaha tersebut menjadi lebih berkembang, mempunyai produk yang berkualitas dan bernilai jual tinggi sehingga produk usaha tersebut lebih dikenal oleh masyarakat luas.

Digital marketing merupakan salah satu hal penting dalam menjalankan suatu usaha. Para pelaku usaha kecil dan menengah perlu memanfaatkan sosial media sebagai media promosi demi meraih pasar yang lebih luas. Social media marketing adalah proses pemasaran yang dilakukan melalui pihak ketiga, yaitu website berbasis sosial 
media, seperti Instagram, Facebook dan lain-lain (Mustain et al., 2021).

Berikut ini kelompok KKN kami akan memaparkan kelebihan -kelebihan dari pelaksanaan digital marketing:

\section{Kecepatan Penyebaran}

Strategi pemasaran dengan menggunakan media digital dapat dilakukan dengan sangat cepat, bahkan dalam hitungan detik. Selain itu, DM juga dapat diukur secara realtime dan tepat.

\section{Kemudahan Evaluasi}

Dengan menggunakan media online, hasil dari kegiatan pemasaran dapat langsung diketahui. Informasi seperti berapa lama produk Anda ditonton, berapa banyak orang yang melihat produk Anda, berapa persen konversi penjualan dari setiap iklan dan sebagainya. Setelah mengetahui informasi-informasi macam itu, selanjutnya Anda dapat melakukan evaluasi mana iklan yang baik dan buruk. Sehingga Anda dapat memperbaiki untuk periode berikutnya.

\section{Jangkauan Lebih Luas}

Kelebihan berikutnya yaitu jangkauan geografis dari DM yang luas. Anda dapat menyebarkan brand atau produk ke seluruh dunia hanya dengan beberapa langkah mudah dengan memanfaatkan internet.

\section{Murah dan Efektif}

Dibandingkan dengan pemasaran tradisional, tentu saja digital marketing jauh lebih murah dan efektif. Biaya anggaran yang yang dihemat dapat sampai $40 \%$, hal tersebut menurut Gartner's Digital Marketing Spend Report. Selain itu, survey juga menunjukkan bahwa $28 \%$ pengusaha kecil akan berpindah ke digital karena terbukti lebih efektif.

\section{Membangun Nama Brand}

Digital marketing membantu membangun nama brand dengan baik. Eksistensi dunia maya dengan keberadaan brand yang sangat penting karena orang akan melakukan pencarian online sebelum membeli produk.

Tujuan utama dari pelaksanaan kegiatan workshop digital marketing ini adalah kami ingin membantu para pemilik usaha yang ada di kelurahan Rakam untuk memanfaatkan fasilitas teknologi modern yang sudah ada untuk mengembangkan usahanya agar dapat menjangkau lebih banyak lagi sasaran customer dan bisa menjangkau semua wilayah yang terkoneksi dengan internet, sehingga memberikan dampak positif yaitu meningkatkan penjualan dari produk-produk usaha tersebut.

Setelah kegiatan worksop tersebut berakhir kelompok KKN kami membantu para pemilik UMKM dengan cara membuatkan akun media sosial yaitu Instagram dan market place lainnya untuk mempromosikan produk hasil usaha mereka. Kami juga melakukan pelatihan terhadap pemilik UMKM dalam menggunakan media sosial mulai dari cara memposting produk usaha, mempromosikan produk usaha dan cara melakukan transaksi dengan konsumen secara online. Hasilnya adalah salah satu produk UMKM di Kelurahan Rakam yaitu Kripik Talas Romantis milik pak Samsul Rizal mengalami peningkatan penjualan dua kali lipat sehingga menambah pendapatan dan keuntungannya.

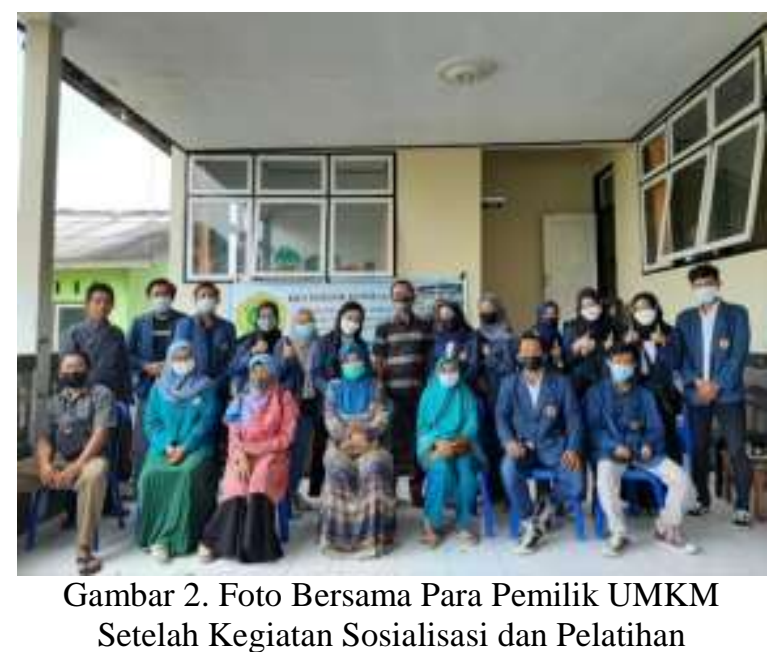

Dengan adanya kegiatan yang kami lakukan ini, diharapkan para UMKM dapat terus mengembangkan usahanya menjadi lebih kreatif dan inovatif dengan memanfaatkan teknologi modern yang telah ada sehingga usaha mereka bisa berkembang lebih maju, dikenal oleh masyarakat luas dan bisa meningkatkan perekonomian dan taraf hidup masyarakat khususnya wilayah kelurahan Rakam. 


\section{Kesimpulan}

Tujuan dari kegiatan pelatihan digital marketing ini yaitu untuk menambah pengetahuan dan pemahaman masyarakat di Kelurahan Rakam tentang pentingnya social marketing dalam menjalankan suatu usaha. Dengan memanfaatkan teknologi modern masa kini kita dapat melakukan promosi dan pemasaran melalui media sosial dan market place lainnya. Dengan menggunakan Digital marketing kita bisa menjangkau lebih banyak sasaran customer dan kita bisa menjangkau semua wilayah yang terkoneksi dengan internet, sehingga berdampak pada peningkatan penjualan produk usaha kita. Selain itu Digital marketing juga bisa menjangkau pasar yang lebih luas. Dengan jangkauan pasar yang lebih luas, maka usaha-usaha yang dikelola oleh UMKM yang ada di kelurahan Rakam tentunya juga dapat dikenal tak cuman di wilayah Kelurahan Rakam saja namun juga di wilayah-wilayah lainnya sehingga peluang mendapatkan customer pun juga semakin besar. Dengan menggunakan dikital marketing kita bisa meningkatkan pendapatan dan keuntungan kita dalam menjalankan suatu usaha. Dengan kegiatan ini UMKM-UMKM yang berada di keluraharn Rakam diharapkan mampu mengembangkan usahanya menjadi lebih maju dan berkembang meskipun sedang menghadapi pandemi covid saat ini.

\section{Ucapan Terima Kasih}

Ucapan terima kasih kami sampaikan kepada Universitas Mataram sebagai Instansi yang memfasilitasi kegiatan $\mathrm{KKN}$ ini sehingga dapat terlaksana dengan baik, kemudian kepada seluruh masyarakat yang ada di Kelurahan Rakam serta semua pihak yang telah membantu selama kegiatan KKN berlangsung.

\section{Daftar Pustaka}

Angellia, F., Cahya, W., Ramadhan, R., \& Hariyansah, I. (2020). Sosialisasi Penggunaan Virtual Meeting Untuk Mendukung Kegiatan Bisnis UMKM di Masa Pandemic Covid 19. Jurnal Pengabdian Teratai, 1(2), 206-213.

Indonesia, R. (2008). Undang-Undang Republik Indonesia Nomor 20 Tahun 2008 tentang usaha mikro, kecil, dan menengah. Republik Indonesia, Jakarta .
Jupri, A., Herlembang, B., Ariyansyah, M. A. J., Anggari, B. Y. I., Rozi, T., \& Prasdyai, E. S. (2021). Pendampingan Branding Packaging dan Digital Marketing Pada Produk UMKM Keripik Talas di Lingkungan Bagek Longgek, Kelurahan Rakam. Jurnal Pengabdian Magister Pendidikan IPA, 4(3).

Mustain, K., Safitri, N., Nurifansyah, N., Munajab, A., Fahira, N. S., Fatihin, M. K., ... \& Saloko, S. (2021). Pengenalan Digital Marketing dan Inovasi Produk "Jeger" Guna Mendukung Pemasaran dan Peningkatan Mutu Kerupuk Singkong di Kel. Geres, Kec. Labuhan Haji, Kab. Lombok Timur. Jurnal Pengabdian Magister Pendidikan IPA, 4(3).

Purwaningsih, E., Suhaeri, S., \& Ariyanti, E. R. N. (2020). Branding Produk UMKM Kampung Wisata Bisnis Tegal Waru melalui Reputasi Merek dan Basis Informasi Teknologi. Abdimas: Jurnal Pengabdian Masyarakat Universitas Merdeka Malang, 5(1), 60-69.

Struggles, H. (2009). The Adoption of Digital Marketing in Financial. Services Under Crisis, 1.

Wahyu, R. (2021). Analisis Kemampuan Wirausaha dan Peluang Usaha terhadap Keberhasilan Usaha pada Kegiatan Pelaku UKM binaan UKM Center Universitas Pembangunan Panca Budi Medan. Kumpulan Karya Ilmiah Mahasiswa Fakultas Sosial Sains, 1(01). 